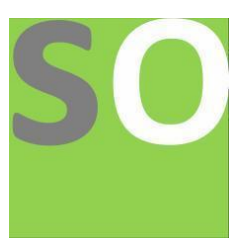

Article title: GIS and Remote Sensing Application in Water Management in Agriculture Field

Authors: Sassi Mohamed Taher[1]

Affiliations: Master of Science MSc[1]

Orcid ids: 0000-0003-1027-8308[1]

Contact e-mail: sassimohamedtaher@gmail.com

License information: This work has been published open access under Creative Commons Attribution License http://creativecommons.org/licenses/by/4.0/, which permits unrestricted use, distribution, and reproduction in any medium, provided the original work is properly cited. Conditions, terms of use and publishing policy can be found at https://www.scienceopen.com/.

Preprint statement: This article is a preprint and has not been peer-reviewed, under consideration and submitted to ScienceOpen Preprints for open peer review.

DOI: 10.14293/S2199-1006.1.SOR-.PPVTPO5.v1

Preprint first posted online: 31 May 2020

Keywords: Remote sensing, Irrigated farming, GIS Application, Water resources management, soil-vegetation-atmosphere transfer process 


\title{
GIS and remote sensing application in water management in agriculture fields
}

\author{
Sassi Mohamed Taher \\ Mediterranean Agronomic Institute of Chania: Geoinformation in Environmental Management \\ department \\ Email : SASSIMOHAMEDTAHER@gmail.com
}

\begin{abstract}
This document is meant to demonstrate the potential uses of remote sensing in managing water resources for irrigated agriculture and to create awareness among potential users. Researchers in various international programs have studied the potential use of remotely sensed data to obtain accurate information on land surface processes and conditions. These studies have demonstrated that quantitative assessment of the soil-vegetation-atmospheretransfer processes can lead to a better understanding of the relationships between crop growth and water management. Remote sensing and GIS was used to map the agriculture area and for detect the change. This was very useful for mapping availability and need of water resources but the problem was concentrating in data collection and analysis because this kind of information and expertise are not available in all country in the world mainly in the developing and under developed country or third world country. However, even though considerable progress has been made over the past 20 years in research applications, remotely sensed data remain underutilized by practicing water resource managers. This paper seeks to bridge the gap between researchers and practitioners first, by illustrating where research tools and techniques have practical applications and, second, by identifying real problems that remote sensing could solve. An important challenge in the field of water resources is to utilize the timely, objective and accurate information provided by remote sensing.
\end{abstract}

Keywords: Remote sensing; Irrigated farming; GIS Application; Water resources management 


\section{Introduction}

Irrigation systems are selected, designed and operated to supply the individual irrigation requirements of each crop field on the farm.

Irrigation is the largest users of freshwater in the world around $70 \%$ of withdrawals are for irrigation. Irrigation produces 30 to $40 \%$ of the world's food crops on $17 \%$ of all arable land (Seckler et al., 1998).

To meet future demands for food with an increasingly scarce water supply, we must manage our water resources better. When water supplies are abundant and environmental pollution and degradation is no issue, water managers can afford to be negligent in its management. But, with growing population and subsequent need for water for food, health and environment, there will be few places in the next century where we have this treat. Management and planning requires good information, and reliable information on water resources use is also at present a scarce resource. The task of providing reliable and accurate information from scales of farmer fields to entire river basins, encompassing millions of hectares of irrigated land, is far from trivial. Space-borne remote sensing measurements can, however, provide regular information on agricultural and hydrological conditions of the land surface for vast areas. The capability of remote sensing and GIS application to identify and monitor crop growth and other related biophysical parameters has undergone major improvements during the last 20 years, albeit several issues remain unresolved.

Remote sensing and Geographic Information System (GIS) with their capability of data collection and analysis are now viewed as efficient and effective tools for irrigation water management. The capability of GIS to analyze the information across space and time would help in managing such dynamic systems as irrigation systems.

\section{Problematic}

The growing dependence on irrigated agriculture coincides with an accelerated competition for water and increased awareness of unintended negative consequences of poor design and management. With the huge acceleration of water use in the Agriculture filed and the limited resources in many region of the world a good practice and management is needed urgent.

Remotely sensed data and GIS are important tools in land and water use planning. 
Presently, still the main problem is that discussions with water managers and policy makers have revealed that this community is quite often unaware of the new technical possibilities, partly because the discussion about remote sensing remains within the remote sensing community.

\section{Methodology}

Satellites measure spectral radiance, they do not give direct information on yield, salinity, or other information. There are a number of steps that must be taken to bring out useful information.

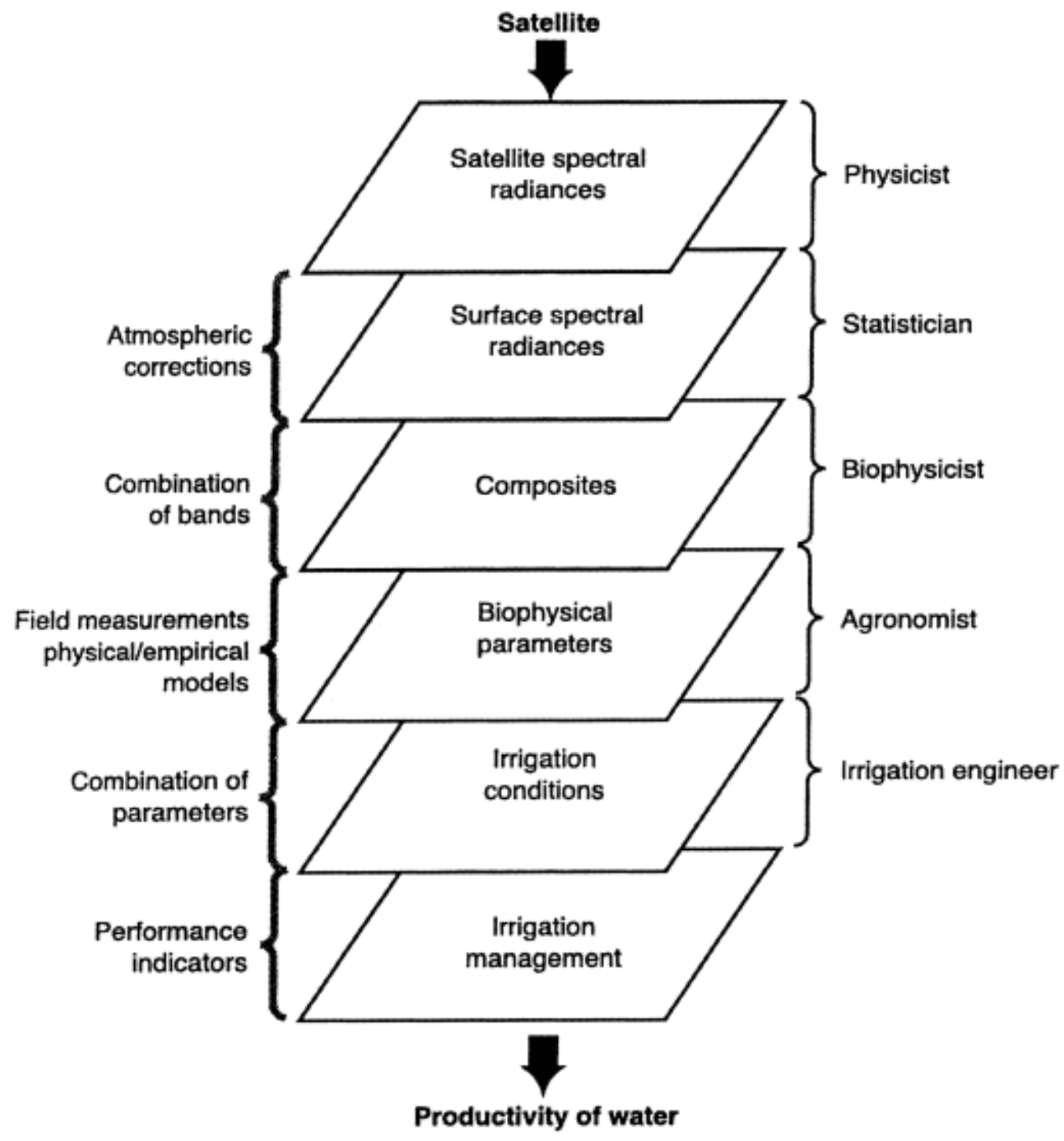

Figure: 1 sequence of procedures needed to interpret satellite spectral measurements for use in practical water management. 
A methodology was developed using a Geographic Information System (GIS) to select, design, install and manage an irrigation system for a farm. GIS was used to develop different thematic layers, each consisting of a particular attribute required for analysis of alternative irrigation system types. These layers included data such as: topography, soil texture, soil water retention, bulk density, infiltration rate of water and field drainage system.

These layers were used with water availability and water demand to design and plan the farm irrigation systems. Here we mention some reviews related to this study : Hazrat et al. (2003) found that the GIS is an important tool that can be used for optimal allocation of water resources of an irrigation project. Chowdary et al. (2008) showed that satellite remote sensing coupled with GIS offers an excellent alternative to conventional mapping techniques in monitoring and mapping of surface and sub-surface waterlogged areas. El Nahry et al. (2011) found that for center pivot irrigation under precision farming, remote sensing and GIS techniques have played a vital role in the variable rate of water applications that were defined due to management zone requirements. Fertilizers were added at variable rates. We do not forgot also the problem of salinity Utset \& Borroto (2001) used the GIS to create raster layers with soil electrical conductivity and topographical altitudes to determine the border of saline effect zones. Szalai et al. (2004) analysed several applications of the GIS in climatology, meteorology and regional evapotranspiration, as well as, to determine irrigation requirements. Xiaopveng et al. (2011) developed an irrigation scheduling method by integrating the 'checkbook irrigation method' into a GIS-coupled soil water and nitrogen management model.

\section{Results and discussion}

Remote sensing has the possibility of offering important water resource-related information to policy makers, managers, consultants, researchers and to the general public. Remote sensing, with varying degrees of accuracy, has been able to provide information on land use, irrigated area, crop type, biomass development, crop yield, crop water requirements, crop evapotranspiration, salinity, water logging and river runoff. This information when presented in the context of management can be extremely valuable for planning and evaluation purposes (see Table 1). 
Table1: Remote sensing products for water management

\begin{tabular}{lllllll}
\hline $\begin{array}{l}\text { Remote sensing } \\
\text { deliverables }\end{array}$ & $\begin{array}{l}\text { Water use/ } \\
\text { productivity }\end{array}$ & $\begin{array}{l}\text { Performance } \\
\text { diagnosis }\end{array}$ & $\begin{array}{l}\text { Strategic } \\
\text { planning }\end{array}$ & $\begin{array}{l}\text { Water } \\
\text { rights }\end{array}$ & Operations & $\begin{array}{l}\text { Impact } \\
\text { assessment }\end{array}$ \\
\hline $\begin{array}{l}\text { Land use } \\
\text { Irrigated area }\end{array}$ & $\checkmark$ & $\checkmark$ & $\checkmark$ & & & \\
Crop type & $\checkmark$ & $\checkmark$ & $\checkmark$ & $\checkmark$ & $\checkmark$ & $\checkmark$ \\
Crop yield & $\checkmark$ & $\checkmark$ & $\checkmark$ & $\checkmark$ & $\checkmark$ & $\checkmark$ \\
$\begin{array}{l}\text { Daily ET } \\
\text { Seasonal ET }\end{array}$ & $\checkmark$ & $\checkmark$ & $\checkmark$ & $\checkmark$ & & $\checkmark$ \\
Crop stress & & $\checkmark$ & & & $\checkmark$ & $\checkmark$ \\
Salinity & & $\checkmark$ & & & $\checkmark$ \\
Historical data & & $\checkmark$ & $\checkmark$ & $\checkmark$ & & $\checkmark$ \\
\hline
\end{tabular}

${ }^{\mathrm{a}} \mathrm{ET}=$ evapotranspiration.

Remote sensing has several advantages over field measurements. First, measurements derived from remote sensing are objective; they are not based on opinions. Second, the information is collected in a systematic way which allows time series and comparison between schemes. Third, information can be spatially represented through geographic information systems, revealing information that is often not apparent when information is provided in tabular form. Besides Remote sensing may now provide viable solutions in some situations, allowing repeated sampling of field conditions in units as small as 100 ha. By regularly monitoring field wetness indicators, system managers can modify decisions throughout an irrigation season based on field moisture depletion and evaporation deficit.

The main result of this study is the answer of this question: How can water be best redistributed in a given system to increase the overall productivity of the system? The combination between GIS application and remotely sensing data can perform monitoring of irrigation system with good management practice by equal distribution of the water for all the users in a sustainable way. This table presented above show what are the different sensor that can be used in water management 
Table 2: Sensors or satellites that provide images suitable for agricultural water management

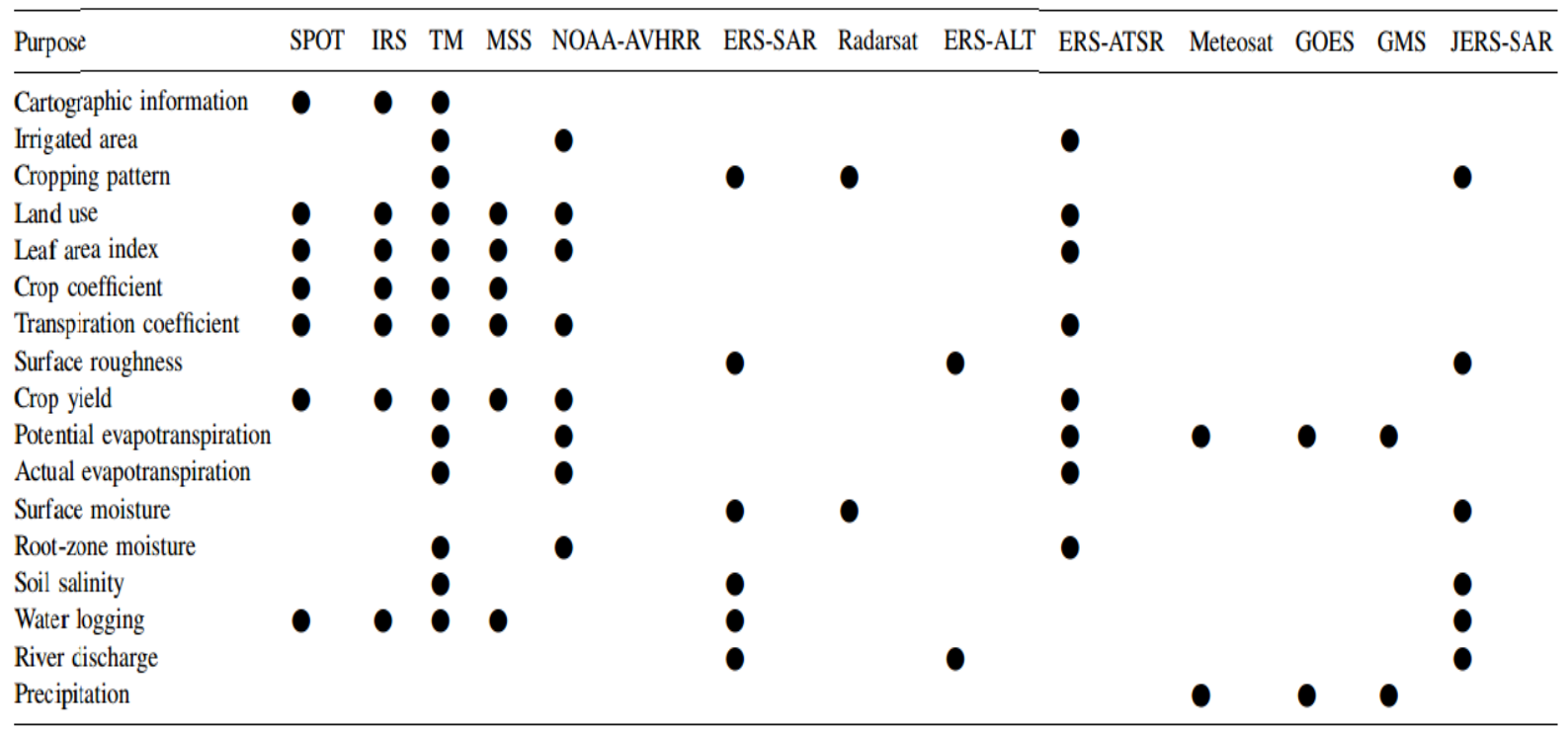

\section{Conclusion}

With increasing pressures on water resources, patterns of water use are in a state of change. It is essential to develop and rethink long-term strategies to meet challenges. Strategic or longterm planning is implemented through legislation and policies. Strategic water use requires good information on irrigated areas, cropping patterns, evaporative use and historic use of water. Information from ground sources is often based on design data rather than actual figures. Studies on irrigated areas taken from remotely sensed data and GIs application present the best performance although additionally AUTOCAD can be also used to design the irrigation method. 


\section{References}

Eduardo Antonio Holzapfel Hoces, José Luis Arumí, Antonieta Rodríguez \& Vital Pedro da Silva Paz . October 30, 2012 : Geographic information system supported farm irrigation system design and planning

Wim G.M. Bastiaanssen, David J. Molden, Ian W. Makin ; International Water Management Institute, P.O. Box 2075, Colombo, Sri Lanka 10 January 2000 : Remote sensing for irrigated agriculture: examples from research and possible applications

P.Maurel, A. Vidal, A.Lahou 1993 : Integration of remote sensing and GIS for the management of large irrigation projects

Díaz A , M P González-Dugo , S Escuin , L Mateos , F Cano , V Cifuentes , J L Tirado , N Oyonarte . 2010: Irrigation water use monitoring at watershed scale using series of highresolution satellite images

NICOLAOS P. THEODOSSIOU 19 November 2003 : Application of Non-Linear Simulation and Optimisation Models in Groundwater Aquifer Management

Michel Lepage, Vincent Simonneaux, Sonia Thomas , JØrome Metral , Benoît Duchemin, Hakim Kharroun, Mohamed Cherkaoui , Abdelghani Chehbouni : SAMIR a tool for irrigation monitoring using remote sensing for evapotranspiration estimate

Diofantos G. Hadjimitsis and Giorgos Papadavid. chap 2013 : Remote Sensing for Determining Evapotranspiration and Irrigation Demand for Annual Crops

Amor V.M. Ines, Kiyoshi Honda, Ashim Das Gupt, Peter Droogers, Roberto S. Clemente 2006 : Combining remote sensing-simulation modeling and genetic algorithm optimization to explore water management options in irrigated agriculture

O. Adeniyi 1993 : Integration of remote sensing and GIS for Agricultre resources management in Nijeria. Peter 